\title{
Sistematização das artérias da base do encéfalo e suas fontes de suprimento sangüíneo em nutria (Myocastor coypus)*
}

\author{
RODRIGO CAVALCANTI DE AZAMBUJA
}

\author{
Rui Campos (Orientador - UFRGS)
}

Banca: Amilton Vallandro Marçal (PUC-RS Uruguaiana), Luciana Silveira Flores Schoenau (UFSM), Maria Cristina Faccioni Heuser (UFRGS).

Neste trabalho estudou-se as artérias da base do encéfalo e suas fontes de suprimento sangüíneo em nutria (Myocastor coypus). Foram utilizados 32 espécimes. Em 30 animais, o sistema arterial foi preenchido com látex 603 corado em vermelho através da artéria aorta. Duas fêmeas foram utilizadas na confecção de moldes acrílicos. Sistematizou-se a origem das fontes de suprimento sangüíneo para o encéfalo e as artérias $(\mathrm{Aa})$ da face ventral do cérebro, à direita $(\mathrm{D})$ e à esquerda $(\mathrm{E})$, com suas respectivas percentagens de aparecimento. $\mathrm{O}$ arco aórtico emitiu o tronco braquiocefálico e a artéria (A.) subclávia $\mathrm{E}(60 \%)$ ou tronco braquiocefálico, A. carótida comum E e A. subclávia E (40\%). O tronco braquiocefálico lançou A. carótida comum D e E e A. subclávia D (60\%) ou A. carótida comum D e A. subclávia D (40\%). A A. carótida comum D e E dividiu-se em A. carótida externa e A. occipital. A A. carótida interna foi ramo da A. occipital (100\%), à D e E, e não cooperou na irrigação encefálica. Ramos terminais das Aa. Vertebrais D e E presentes (100\%) formaram a A. basilar (100\%). A. espinhal ventral presente (100\%). A. cerebelar caudal à D foi simples (60\%), dupla (36,7\%) e tripla (3,3\%), e à E foi simples $(60 \%)$ e dupla (40\%). A. cerebelar média como ramo da A. cerebelar caudal à D (70\%) e à E (73,3\%). A. trigeminal D e E ímpar (100\%). A. cerebelar rostral D, simples (73,3\%) e dupla (26,7\%), à E, simples (70\%) e dupla (30\%). A. cerebral caudal D, simples (66,7\%) e dupla (33,3\%), à E, simples (73,3\%) e dupla (26,7\%). A. hipofisária D e E ímpar presente (100\%). A. cerebral média D e E ímpar presente (100\%). A. cerebral rostral D, desenvolvida e ímpar (86,7\%), dupla (10\%) e ausente (3,3\%), à E desenvolvida e ímpar (100\%). Ramo medial da A. cerebral rostral D, ímpar e desenvolvido (66,7\%), vestigial $(23,3 \%)$ ou ausente (10\%), à E, ímpar e desenvolvido $(73,3 \%)$, vestigial $(23,3 \%)$ e ausente $(3,3 \%)$. A. inter-hemisférica rostral presente $(100 \%)$, formada pela anastomose do ramo medial da A. cerebral rostral D e E (40\%), formada apenas pelo ramo medial da A. cerebral rostral E (33,3\%) e formada apenas pelo ramo medial da A. cerebral rostral D (26,7\%). A. lateral do bulbo olfatório D e E presente e ímpar (100\%). A. medial do bulbo olfatório D e E ímpar (100\%). A. etmoidal interna D simples (96,7\%) e dupla (3,3\%), à E, simples (100\%). Observou-se que o círculo arterial cerebral da nutria foi fechado caudalmente (100\%) e rostralmente aberto (60\%) ou fechado (40\%). O encéfalo foi suprido exclusivamente pelo sistema vértebro-basilar.

Descritores: anatomia animal, Myocastor coypus, artérias: cérebro, irrigação encefálica: roedores.

Apresentada: 06 março 2006

"Dissertação de Mestrado n. 431 (Especialidade: Anatomia Animal). 151f. Programa de Pós-graduação em Ciências Veterinárias [www.ufrgs.br/ ppgcv], Faculdade de Veterinária, Universidade Federal do Rio Grande do Sul (UFRGS), Porto Alegre, RS/Brasil. CORRESPONDÊNCIA: R.C. Azambuja [rodrigo_azambuja@yahoo.com.br]. 


\title{
A systematic study of the brain base arteries and their sources blood's supply in the nutria (Myocastor coypus)**
}

\author{
RODRIGO CAVALCANTI DE AZAMBUJA
}

\author{
Rui Campos (Adviser - UFRGS)
}

Committee: Amilton Vallandro Marçal (PUC-RS Uruguaiana), Luciana Silveira Flores Schoenau (UFSM), Maria Cristina Faccioni Heuser (UFRGS).

In this research the brain base arteries and its blood supply irrigation's source in nutria (Myocastor coypus) were studied. 32 specimens were used. In 15 females and 15 males, the arterial system was filled with colored latex 603 through the aorta. Two females were utilized to produce acrylic models. The arteries to the blood irrigation's sources and to the ventral surface of the brain were systematized, on the right $(\mathrm{R})$ and on the left $(\mathrm{L})$ sides, with respective percentages of appearance. The aortic arch emitted the braquicephalic trunk and the left subclavian artery (60\%) or the braquicephalic trunk, the L common carotid artery and the L subclavian artery (40\%). The braquicephalic trunk emitted the $\mathrm{L}$ and the $\mathrm{R}$ common carotid arteries and the R subclavian artery (60\%) or the R common carotid artery and the R subclavian artery (40\%). The R and the L commons carotid arteries divided into external carotid artery and occipital artery. The internal carotid artery was a branche of the occipital artery, on the R and on the L (100\%) and in all cases didn't supply the encephalic vascularization. The terminal branches of the $\mathrm{R}$ and $\mathrm{L}$ vertebral arteries present $(100 \%)$ were forming the basilar artery $(100 \%)$ The caudal cerebellar artery was, on the R single (60\%), double (36,7\%) and triple (3,3\%); on the L, single (60\%) and double (40\%). The middle cerebellar artery was a branche of the caudal cerebellar artery, on the $\mathrm{R}(70 \%)$ and on the $\mathrm{L}(73,3 \%)$. The trigeminal artery was single (100\%) in both sides. The rostral cerebellar artery, on the R, single (73,3\%) and double $(26,7 \%)$, and on the L, single (70\%) and double (30\%). The caudal cerebral artery, on the R, single $(66,7 \%)$ and double $(33,3 \%)$, and on the L, single $(73,3 \%)$ and double $(26,7 \%)$. The hypophiseal artery was present $(100 \%)$ in both sides. The middle cerebral artery was single (100\%) in both sides. The rostral cerebral artery, on the R, single (86,7\%), double (10\%) and absent (3,3\%), and on the L, single (100\%). The medial branche of rostral cerebral artery, on the R, developed and single (66,7\%), vestigial $(23,3 \%)$ and absent (10\%), on the L, developed and single $(73,3 \%)$, vestigial $(23,3 \%)$ and absent $(3,3 \%)$. The rostral inter-hemispheric artery present (100\%) was originated: from the union of the medial branches of the, $\mathrm{R}$ and $\mathrm{L}$, rostral cerebral arteries (40\%), only from the medial branche of the $\mathrm{L}$ rostral cerebral artery $(33,3 \%)$ and only from the medial branche of R rostral cerebral artery $(26,7 \%)$. The lateral olfactory bulb artery was present and single (100\%) in both sides. The medial olfactory bulb artery was present and single (100\%) in both sides. The ethmoidal artery, on the R, single (96,7\%) and double (3,3\%), and on the L, single (100\%). The nutria's cerebral arterial circle was closed caudally $(100 \%)$ and it was rostrally open $(60 \%)$ or closed $(40 \%)$. The brain was exclusively supplied by the vertebral-basilar system.

Key words: nutria, Myocastor coypus, brain base arteries, encephalic vascularization: rodents.

Presented: 06 March 2006

\footnotetext{
**Master's Thesis \# 431 (Field: Animal Anatomy). 151p. Graduated Program in Veterinary Sciences [www.ufrgs.br/ppgcv], Faculdade de Veterinária, Universidade Federal do Rio Grande do Sul (UFRGS), Porto Alegre, RS/Brazil. CORRESPONDENCE: R.C. Azambuja [rodrigo_azambuja@yahoo.com.br].
} 